\title{
Study of Drying Characteristics of Bottle Gourd in Tray Dryer
}

\author{
${ }^{1}$ K.A. Shinde, ${ }^{2}$ S.G. Pawar, ${ }^{3}$ S.U. Khodke \\ ${ }^{1}$ K.A. Shinde, M.Tech. Scholar, Deptt. of Agricultural Process Engineering, Vasantrao Naik \\ Marathawada Agriculture University, Parbhani-431402, Maharashtra. \\ ${ }^{3}$ S.U. Khodke, Associate Professor, Deptt. of Agricultural Process Engineering, Vasantrao Naik \\ Marathawada Agriculture University, Parbhani-431402, Maharashtra. \\ ${ }^{2}$ Pawar S.G., Ph.D. Scholar, Deptt. Of Agricultural Process Engineering, Dr. Panjabrao Deshmukh \\ Krishi Vidhyapith, Akola-44104, Maharashtra. \\ savityapawar100@gmail.com
}

\begin{abstract}
The study was undertaken to investigate the drying characteristics of bottle guard powder experimentally. Bottle gourd powder was prepared by varying process parameters i.e. steam blanching time (2, 4, 5 and $8 \mathrm{~min}$ ) and drying air temperature $\left(50,60,70\right.$ and $\left.80^{\circ} \mathrm{C}\right)$ and one without blanched sample was evaluated for each drying air temperature. The bottle gourd shreds were subjected to thin layer hot air drying in a cabinet dryer keeping constant air velocity of $1.5 \mathrm{~m} / \mathrm{sec}$. The total average drying time required to attain the average moisture content of $0.04 \mathrm{~kg}$ water per $\mathrm{kg} \mathrm{dm}$ at drying temperature of 50, 60, 70 and $80^{\circ} \mathrm{C}$ was 660 , 480, 420 and 345 minutes, respectively. The optimum values of steam blanching pre treatment $(6$ min) prior to hot air drying $\left(60^{\circ} \mathrm{C}\right)$ was found to be the most effective treatment to obtain better quality bottle gourd powder.
\end{abstract}

Keywords: bottle gourd, steam blanching, drying and drying characteristies

\section{INTRODUCTION}

Bottle gourd (Lagenaria siceraria mol. Stand L.) is an important vegetable crop of tropical and sub tropical regions of the world belonging to the family cucurbitaceae. Bottle gourd has it's origin in India and Africa. It is very popular in Indo-Pakistan sub continent and cultivated throughout India almost all the year round and hence the fruit are always available in the market. India is second largest producer of bottle gourd in the world over after china (Tomar, et al., 2007). It is being cultivated widely in Maharashtra. Cultivators in western Maharashtra and Northern Kokan region are cultivating this crop in commercial scale.

Bottle gourd are consumed in a number of ways like doodhi halwa, kofta, petha and tutifruity. The fruit is having high medicinal value of considerable importance. Bottle gourd is good source of Vitamin B and ascorbic acid. Bottle gourd is having cool effect on human body and easy to digest. It gives relief to patients suffering from urinary disorders, heart problems, insomnia and diabetes (Gopalan et al., 2000). Bottle gourd is very useful to maintain cholesterol level in blood and reduces the impact of low blood pressure and heart diseases which are found most commonly among people.

Along with nutritional value it has also great therapeutic value in the experiment conducted on rat and bottle gourd fruit extract show marked hypolipidemic activity (Ghante et al., 2006).

Bottle gourd pulp is good for overcoming constipation, cough, night blindness and as an antitode against certain poison (Chauhan, 1972).

According to Ayurveda and unani, bottle gourd is cardiotonic, laxative cooling, diuretic, antebellum whole some to the foctus, tonic to liver, antiperodic, antipyretic (Kirtikar and Basu, 1991).

The edible portion of bottle gourd fruit contains moisture (96.3 per cent), total soluble solids (3.5 ${ }^{0}$ Brix $)$, acidity $(0.12$ per cent $)$ carbohydrates $(2.9$ per cent $)$, protein $(0.2$ percent $)$, fat $(0.1$ per cent $)$, minerals $(0.5$ per cent), fibre $(0.6$ per cent), thiamine $(0.044 \mathrm{mg})$, riboflavin $(0.023 \mathrm{mg})$, niacin $(0.33$ $\mathrm{mg}$ ) and ascorbic acid (13 mg) per $100 \mathrm{~g}$ (Desai and Musmade, 1998).

Bottle gourd contain Ca (12 mg), P (37 mg), Na (1.7 mg), K (87 mg), Cr (0.05 mg), Fe (0.8 mg), per $100 \mathrm{gm}$ of bottle gourd fruit. Minerals are important for vital body functions such as acid base and water balanace. (Rumezan et al., 2006). 


\section{K.A. Shinde et al.}

Drying is the term used to remove the moisture from vegetable or fruit upto a predetermined level. Powder is a source of vitamins, minerals and other nutrients. Drying helps to increase shelf life of bottle gourd powder, easy to use and transportation of bottle gourd powder.

The bottle gourd is having tremendous health benefits. The process for consuming fresh bottle gourd to meet daily recommended requirement is tedious one for the want of regularity in adopting bottle gourd to hatch its benefits, one can avoid pains and drudgery involved in processing of bottle gourd before consuming by adopting simply in powder form. In order to ease the adoption of bottle gourd, it needs to be converted into dried powder form so as to make it available as and when required.

The powder from bottle gourd will also helps to start small scale industries in urban areas as market for these products is increasing now a days. Preparation of bottle gourd powder is one of the viable technology for utilization of bottle gourd fruits. This will helps to increase the area under such an important vegetable crop and to give good returns to bottle gourd cultivators thus improving their economic condition.

\section{MATERIALS AND METHODS}

\subsection{Raw Materials}

Fresh light green, well matured, uniform size and colour bottle gourd of Samrat variety were obtained from local market to the laboratory. After washing and sorting graded bottle gourds were cut into two halves along it's vertical axis, unedible portion were scooped out with the help of spoon and then cut into shreds. Thickness of shreds was maintained $3 \mathrm{~mm}$ with the help of stainless steel knife. A deep pot with tight fitting lid and a wire basket was used for steam blanching. The water was added to the pot and brought to a rolling boil. Bottle gourd shreds were kept at 2 inches deep loosely in the basket. Basket with shreds was placed in the pot making sure that water does not come in contact with the bottle gourd shreds. Pot was covered for varying blanching time as 2, 4, 6 and 8 min respectively. The bottle gourd shreds were subjected to thin layer hot air drying in a cabinet dryer keeping constant air velocity of $1.5 \mathrm{~m} / \mathrm{sec}$. Drying temperature was chosen as independent variable in the range of 50 to $80^{\circ} \mathrm{C}$.

\subsection{Experimental Plan}

\begin{tabular}{|l|c|c|c|c|}
\hline Blanching time $(\min )$ & 2 & 4 & 6 & 8 \\
\hline Drying temperature $\left({ }^{0} \mathrm{C}\right)$ & 50 & 60 & 70 & 80 \\
\hline
\end{tabular}

The control sample was taken as without blanched bottle gourds shreds dried at above drying temperature levels.

Total twenty experiments such as sixteen experiments + four experiments (without blanched sample, control) were conducted to see the effect of independent variables such as steam blanching time and drying temperature on various quality attributes of dried products. The experiments were replicated thrice and data were recorded.

\subsection{Analysis of Drying Data}

Drying data recorded for blanched bottle gourd shreds in a thin layer hot air drying are presented in Appendix $B_{1}$, through Appendix $B_{20}$. The observed drying data i.e. weight loss of sample with time for each drying parameters such as moisture content, average moisture content and drying rate $(\mathrm{kg}$ water per $\mathrm{kg} \mathrm{dm} \mathrm{hr),} \mathrm{Moisture} \mathrm{Ratio} \mathrm{(MR)} \mathrm{and} \ln (\mathrm{MR})$ using standard techniques. The values of drying parameters for three replications were averaged to get the data for each drying run.

\subsubsection{Drying Rate}

Drying rate were computed by recording the loss in weight at 15 min interval. The sample drying rate was expressed as $\mathrm{kg} / \mathrm{kg} \mathrm{dm} \mathrm{hr}$ and calculated

$$
\text { Drying rate }(R)=\frac{\text { Amount of moisture removed }}{(\text { Time }(\text { hr }) \times \text { total bone dry weight of material } \div 100)} \mathrm{kg} / \mathrm{kg} \mathrm{dm} \mathrm{hr}
$$

\subsubsection{Moisture Ratio (MR)}

The drying data were used to compute Moisture Ratio (MR) from the following relationship 
$M R=\frac{M_{t}-M_{e}}{M_{o}-M_{e}}$

Where,

$M_{t}=$ Moisture content at time $\mathrm{t}, \mathrm{Kg}$ water per $\mathrm{Kg} \mathrm{dm}$

$M_{e}=$ Equilibrium moisture content, $\mathrm{Kg}$ water per $\mathrm{Kg} \mathrm{dm}$

$M_{o}=$ Initial moisture content at time $\mathrm{t}=0, \mathrm{Kg}$ water per $\mathrm{Kg} \mathrm{dm}$

The logarithms of moisture ratio (ln MR) were also computed.

\section{RESUlt AND DISCUSSION}

\subsection{Effect of Process Variables on Drying Time}

Total drying time required to dry the steam blanched bottle gourd shreds continuously from a uniform initial moisture content of $11.5 \mathrm{~kg}$ water per $\mathrm{kg} \mathrm{dm}$ to its near equilibrium safe value $0.04 \mathrm{~kg}$ water per $\mathrm{kg} \mathrm{dm}$ was calculated by interpolation of the drying curves for all drying conditions for better comparison and are presented in Table 3.1.

Table 3.1 showed that drying time required for reducing initial moisture content to shelf storage moisture content $(0.04 \mathrm{~kg}$ water per $\mathrm{kg} \mathrm{dm})$ under different drying air temperature.

Table3.1. Drying time required for reducing initial moisture content to shelf storage moisture content $(0.04 \mathrm{~kg}$ water per $\mathrm{kg} \mathrm{dm}$ ) under different drying air temperature.

\begin{tabular}{|c|c|}
\hline Drying temperature $\left({ }^{0} \mathrm{C}\right)$ & Average drying time (min) \\
\hline 50 & 660 \\
\hline 60 & 480 \\
\hline 70 & 420 \\
\hline 80 & 345 \\
\hline
\end{tabular}

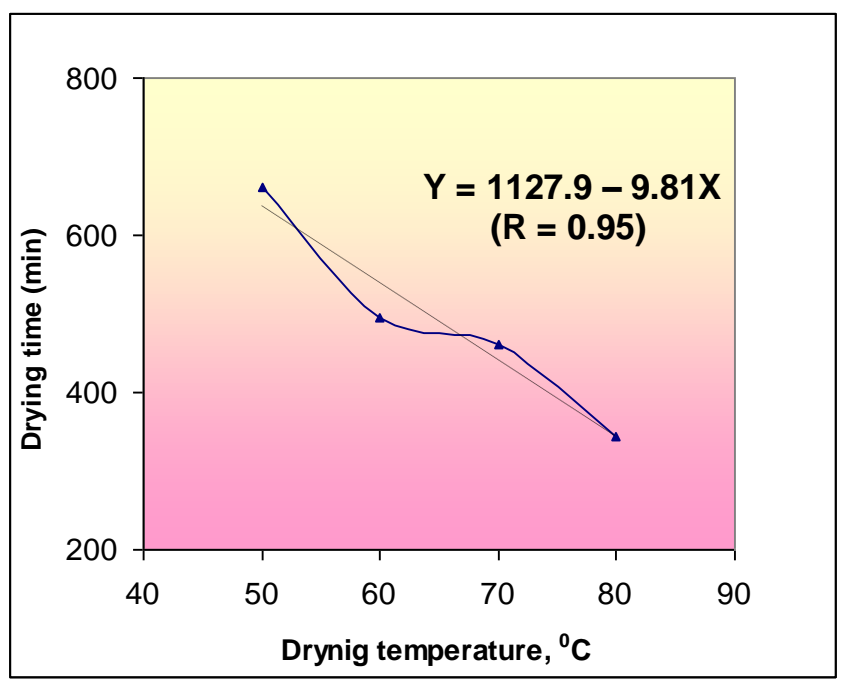

Fig3.1. Effect of drying temperature on drying time

The total average drying time required to attain the average moisture content of $0.04 \mathrm{~kg}$ water per $\mathrm{kg}$ $\mathrm{dm}$ at drying temperature of $50,60,70$ and $80^{\circ} \mathrm{C}$ was $660,480,420$ and 345 minutes, respectively (Table 3.1). It is evident from table 3.1 that total drying time decreased with increase in drying air temperature. At $50^{\circ} \mathrm{C}$, the time taken to dry sample to safe storage moisture content was 660 minutes compared to only 345 minutes at $80^{\circ} \mathrm{C}$ drying air temperature. The mechanism governing loss of moisture during drying has been studied extensively and number of researchers proposed vapour pressure theory of drying (Brooker D.B. et al. 1974 and Hall C.W. (1970).

In general there was an increase in required drying time at lower drying air temperature, which might be due to case hardening of product at lower drying air temperature. On the other hand reduction in required drying time with an increase in drying air temperature under all the treatments was observed which might be due to i) increased vapour pressure within the product which resulted in faster migration of moisture to the surface and ii) decreased relative humidity of drying air enhancing moisture removal rate from the product surface. 


\section{K.A. Shinde et al.}

\subsection{Effect of Process Variables on Moisture Content of Bottle Gourd Powder}

The variations in total moisture content of bottle gourd shreds with elapsed drying time at each drying temperatures of 50,60, 70 and $80^{\circ} \mathrm{C}$ are shown in Fig.3.2 (a, b, c, d). These curves followed the typical exponential decay trend as reported for raw potato by earlier researchers (Khraisheh et al.1997d; May et al.2000). The equilibrium moisture content values as observed from Fig. 4.2 through 4.5 were $0.04 \mathrm{~kg}$ water per $\mathrm{kg} \mathrm{dm}$ for the drying temperatures of $50,60,70$ and $80^{\circ} \mathrm{c}$, respectively. Non linearity of drying curves indicated multiple stages of drying process. From the Fig .3.2 (a, b, c, d) it is clear that all drying curves initially exhibited steeper slope indicating higher drying rate.

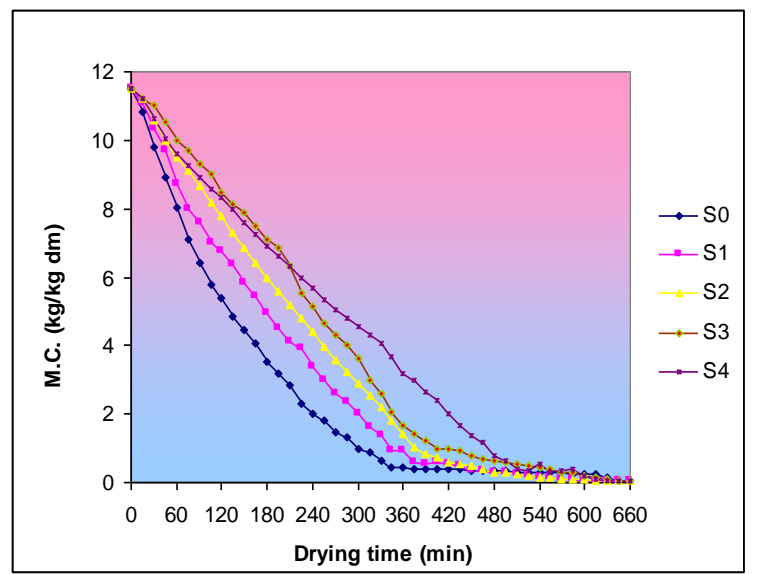

(a)

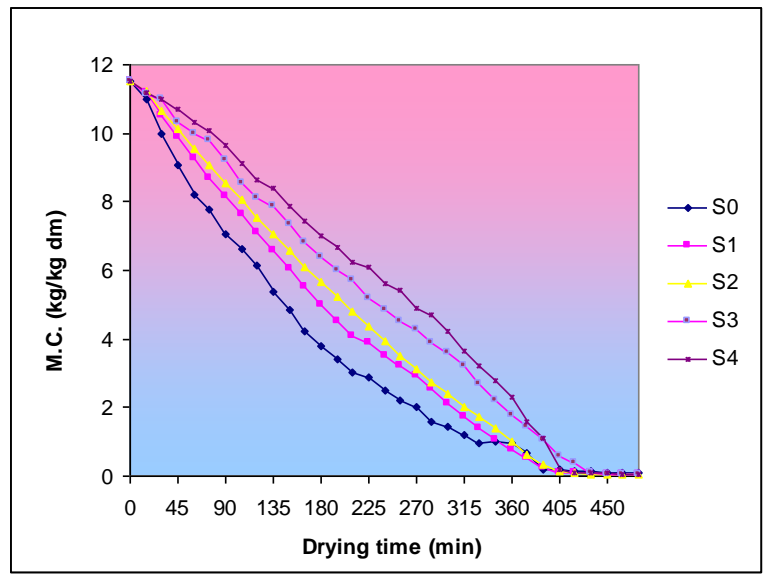

(b)

Fig3.2 (a) and (b). Variation in moisture content of bottle gourd shreds with elapsed drying time at drying air temperature $50^{\circ} \mathrm{C}$ and $60^{\circ} \mathrm{C}$, respectively.

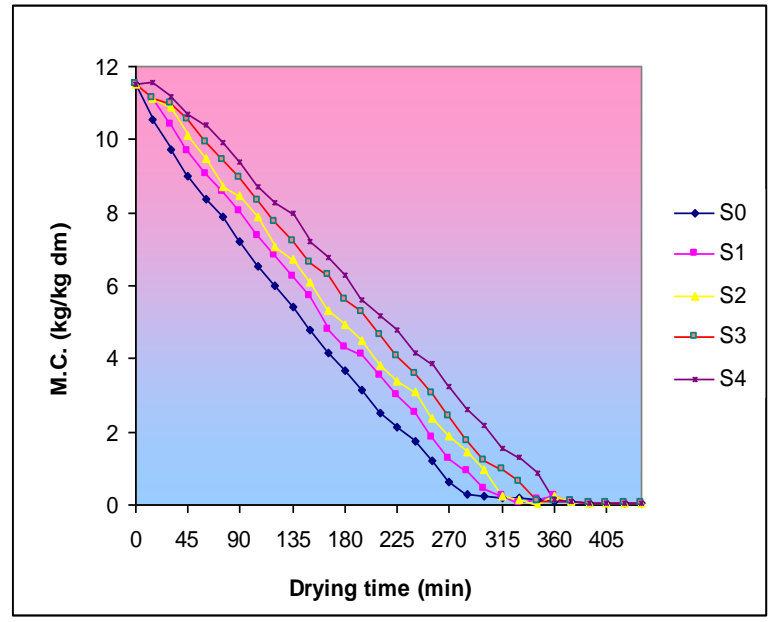

(c)

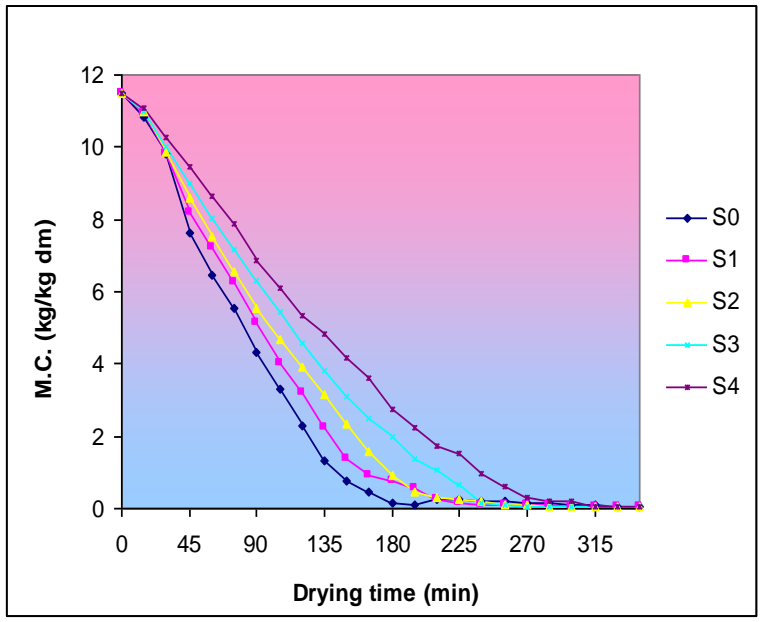

(d)

Fig3.2 (c) and (d) . Variation in moisture content of bottle gourd shreds with elapsed drying time at drying air temperature $70^{\circ} \mathrm{C}$ and $80^{\circ} \mathrm{C}$, respectively

The total drying time for different drying air temperature was plotted in Fig 3.1. The total time taken to dry steam blanched bottle gourd shreds decreased with increase in drying air temperature almost linearly and regression equation for this relationship is also presented in the Figure 3.1.

Equation from figure 3.1 may be useful in predicting the total drying time during simulation process of bottle gourd drying.

\subsection{Effect of Process Variables on Drying Rate.}

Fig 3.3 (a,b,c,d) shows the variation in drying rate of bottle gourd shreds as a function of average moisture content at different air drying temperatures. These drying rates were calculated from the drying data for each drying run, i.e. from the change in moisture content, which occurred in each time interval. Drying rates were $(0.1038$ to $0.5286 \mathrm{~kg} / \mathrm{kg} \mathrm{dm} \mathrm{hr})$ in the beginning of drying at maximum moisture content. 


\section{Study of Drying Characteristics of Bottle Gourd in Tray Dryer}

Johnson et al. (1998) showed that the effect of increasing drying temperature from 50 to $80^{\circ} \mathrm{c}$ did not affect percent moisture lost. With prolonged drying time, drying rate decreased probably due to collapse (Shrinkage) of the banana structure resulting in low transport of moisture (Maskan, 2000)

The variation of drying with the moisture content Fig. 3.3 (a,b,c,d) revealed that within the range variables studied, the drying process was entirely governed by the internal diffusion phenomenon as no constant rate period was observed. Constant rate period is generally observed in drying process, only at the very initial stages with sufficient surface moisture and where the drying rate is controlled by surface evaporation (Charm, 1978). However, at lower temperature and even with constant interval of observation in the drying, constant rate period of drying could not be obtained. Similar to earlier observations as indicated by some studies on fruits and vegetables (Mc Minn and Maggee, 1972).

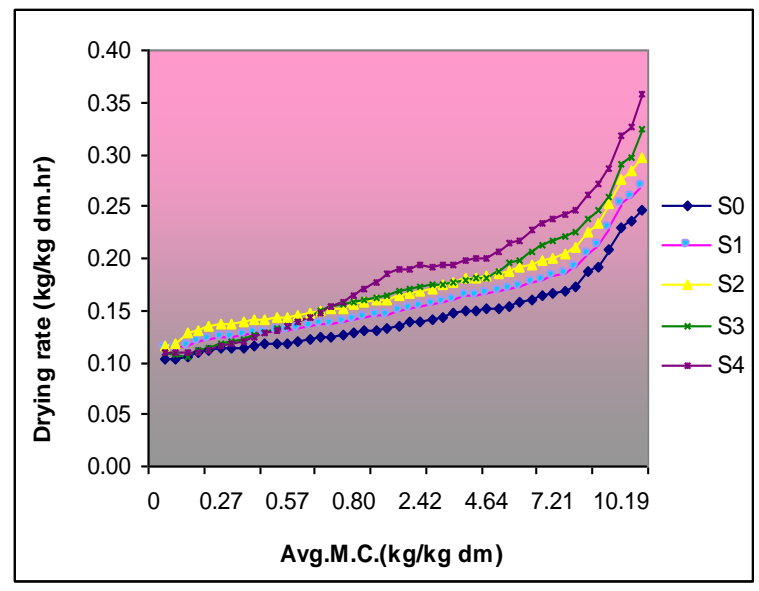

(a)

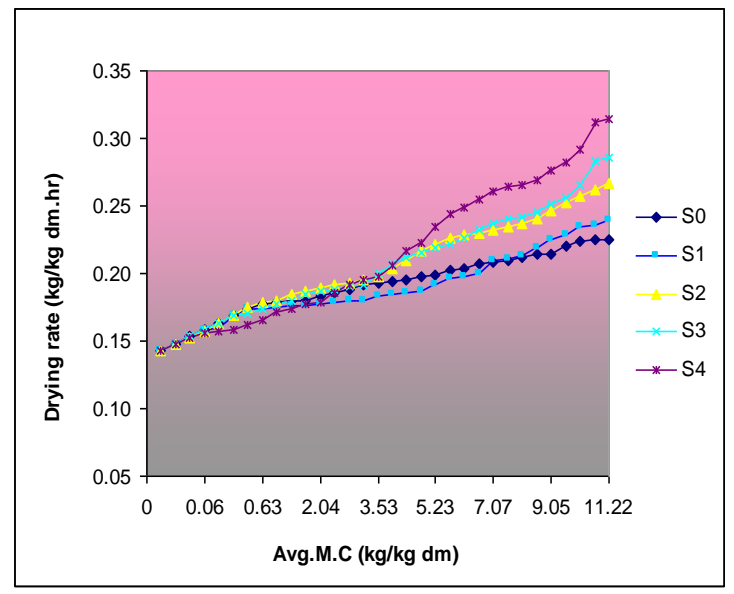

(b)

Fig3.3 (a) and (b). Variation in drying rate with moisture content of bottle gourd shreds at drying air temperature $50^{\circ} \mathrm{C}$ and $60^{\circ} \mathrm{C}$, respectively

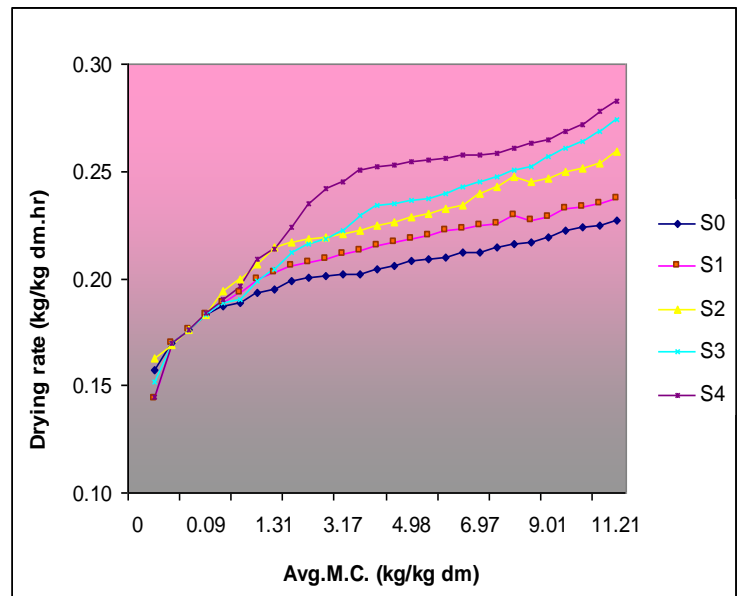

(c)

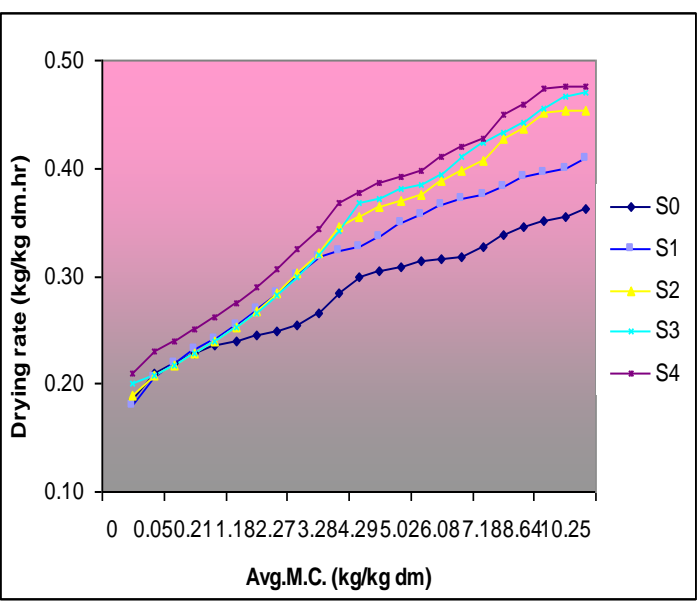

(d)

Fig.3.3 (c) and (d). Variation in drying rate with moisture content of bottle gourd shreds at drying air temperature $70^{\circ} \mathrm{C}$ and $80^{\circ} \mathrm{C}$, respectively.

The decrease in drying rate is due to the temperature rise of the bottle gourd shreds and reduces the moisture content during drying. The extensive dehydration studies reported that the moisture transfer during the drying took place by means of capillary movements towards the surface even though the drying rate was not constant. Abhay et al. (2006) reported similar results that decrease in drying rate with respect to moisture content as the moisture content decrease with the passage of drying time. Kar et al. (2003) reported that the rate of drying decreased with the decrease in moisture content at all drying temperatures. Increased drying temperature from 50 to $80^{\circ} \mathrm{C}$ significantly increased drying rate.

\subsubsection{Effect of drying time on moisture ratio}

The logarithms of moisture ratio (ln MR) were plotted against average drying time ( $t$ ) for difference drying air temperatures and are shown in Fig. 3.10 through 3.13. 


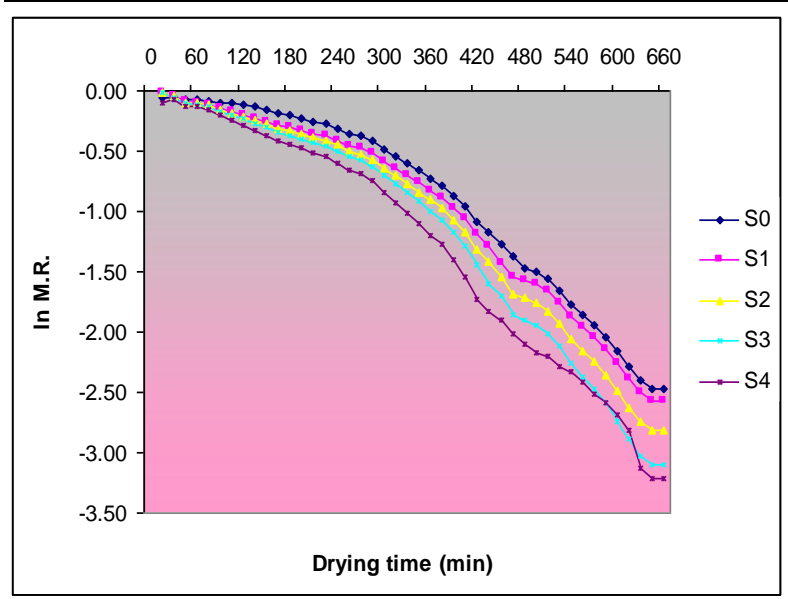

(a)

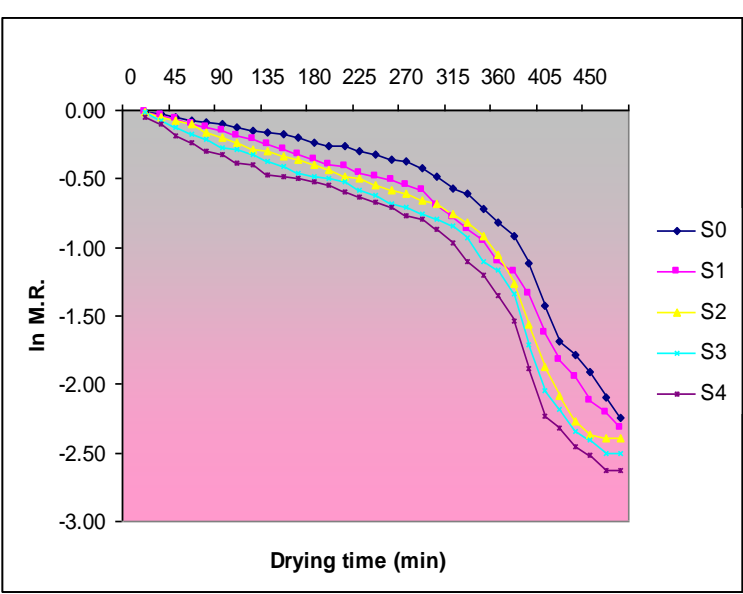

(b)

Fig3.4 (a) and (b). Plot of $\ln M R$ and average drying time for bottle gourd shreds at drying temperature $50^{\circ} \mathrm{C}$ and $60^{\circ} \mathrm{C}$, respectively

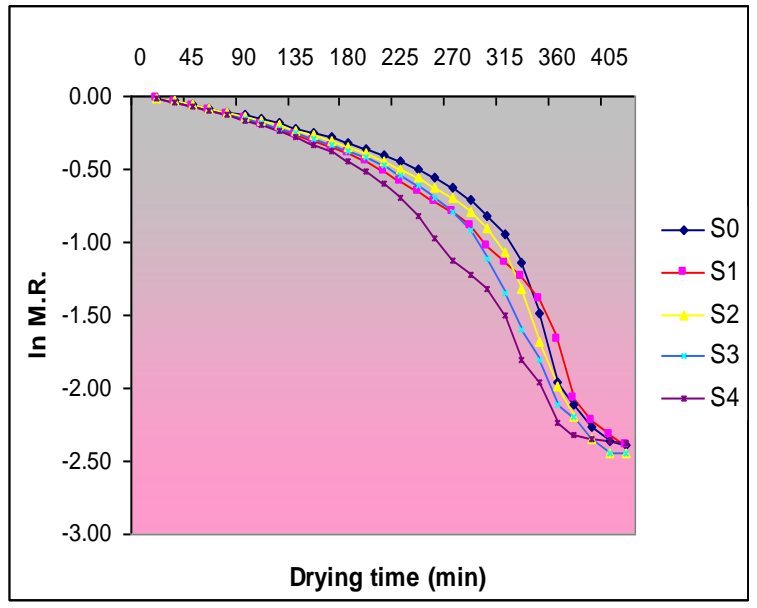

(c)

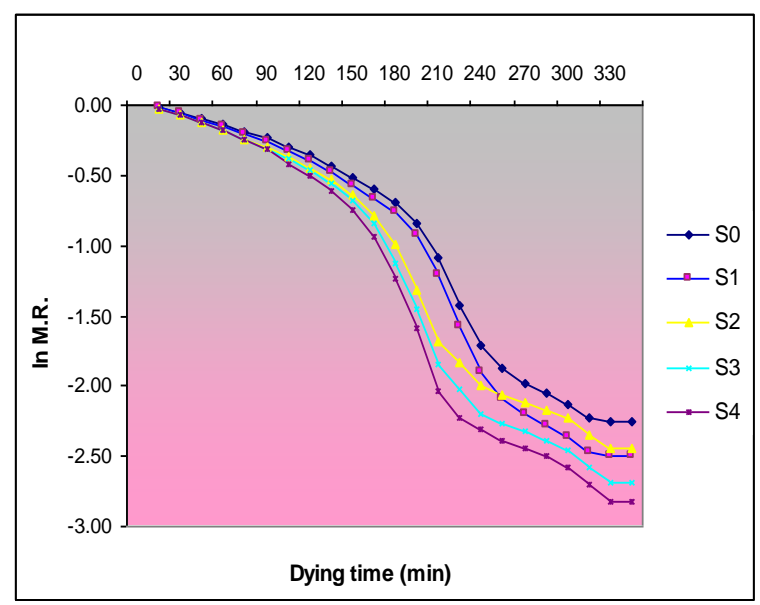

(d)

Fig 3.4 (c) and (d). Plot of $\ln M R$ and average drying time for bottle gourd shreds at drying temperature $70^{\circ} \mathrm{C}$ and $80^{\circ} \mathrm{C}$, respectively

It was observed from the figure that the relationship was non linear in nature for all the drying conditions. This non-linearity in the relationship might be due to reason like shrinkage in product, non uniform distribution of initial moisture and change in product temperature during drying (Hawlader $e t$ al. 1991; Kannan and Bandopadhyay, 1995).

\section{Conclusions}

- Steam blanching treatment prior to hot air drying was found to be most effective pre treatment for better quality attributes of bottle gourd powder.

- Steam blanching pre treatment (6 min) prior to hot air drying $\left(60^{\circ} \mathrm{C}\right)$ was found to be the most effective treatment to obtain better quality bottle gourd powder.

- The bottle gourd powder prepared by the developed process technology was highly consumer acceptable.

\section{REFERENCES}

[1] Abhay, Kr. Thakur, Jain R.K. (2006). Studies on drying characteristics of cauliflower J. Food Science \& Technology 43 (2): 182-185.

[2] Chauhan, D.V.S. (1972). Vegetable production in India. Ram Prasad and Sons, Agra.

[3] Desai, U.T. and Musmade, A.M. (1998). Pumplcins, squashes and gourds in Handbook of vegetable science and Technology (Edited by Salunkhe, D.K. and Kadam, S.S.) marcel Dekker Inc. PP. 279-282. 
[4] Ghante, M.H., Ghule, B.V., Sauji, A.N. and Yeole, P.G. (2006). Hypolipidemic and antihyperlipidemic effect of lagenaria siceraria (mol.) fruit extracts. Indian J. Expt. Biol., 44 (11): 905-909.

[5] Gopalan, C. Rama Sastri, B.V. and Balasubramanian (2000). Nutritive value of Indian Foods. National Institute of Nutrition, Hyderabad.

[6] Hall C.W. (1970). Drying farm crops published by Lyall Book Depot. Ludhiana (India).

[7] Hawlader, M.N.A., Uddin, M.S., HO. J.C. and Teng, A.B.W. (1991). Drying characteristics of tomato. Journal of Food Engineering, 14: 375-391.

[8] Johnson PNT, Brennan J.G. Addo-Yobo F.Y. (1998). Air drying characteristics of plantain (Musa AAB). J. Food. Engineering. 37: 233-242.

[9] Kannan D. and Bandopadhyay, S. (1995). Drying characteristics of a torpical marine fish slab. Journal Food science and Technology, 32 (1): 13-16.

[10] Kar A. Gupta D.K. (2003). Air drying of osmosed button mushrooms. J. Food Science \& Technology 40: 23.27.

[11] Kirtikar, K.R. and Basu, B.D. (1991). Indian medicinal plants Vol. II. Lalit Mohan Basu Pub. Allahabad, India P. 116-118.

[12] Maskan M. (2000). Micro wave/air and microwave finish drying of banana, J. Food. Engineering 44: 71-78.

[13] May, B.K. Sinclair, A.J. Hughes, J.G., Halmos, A.L., Tran, V.N. (2000). A study of temperature and sample dimension in the drying of potatoes drying technology, 18 (10): 2291-2306.

[14] Mcminn, W.A.M. and Magee, T.R.A. (1972). Diffusion analysis during air drying of a starch system, developments in Chemical Engineering, Minerals Proc., 5 (1-2): 60-77.

[15] Rumezan, H., Zafar Z. Shaheena, H. and Masooma, R. (2006). Use of vegetable as nutritional food: Role in human health. J. Agric. And Biol. Sci. 1 (1) : 1-5.

[16] Tomar, B.S., Pham, D. and Singh, B. (2007). Producing hybrid seed of bottle gourd. Indian Hort., 52 (1): 13-15.

\section{AUTHORS' BIOGRAPHY}

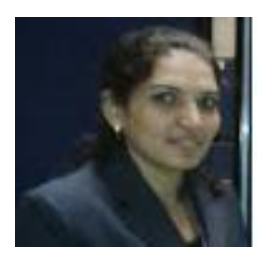

S.G. Pawar, Ph.D. Scholar, Deptt. of Agricultural Process Engineering, Dr. Panjabrao Deshmukh Krishi Vidhyapith, Akola-44104, Maharashtra

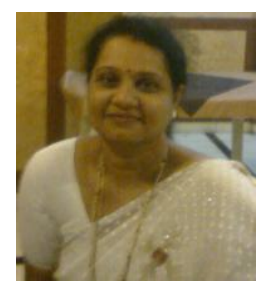

S.U. Khodke, Associate Professor, Deptt. of Agricultural Process Engineering, Vasantrao Naik Marathawada Agriculture University, Parbhani-431402, Maharashtra.

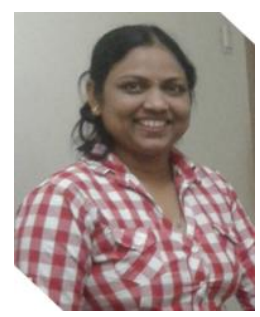

K.A. Shinde, M.Tech. Scholar, Deptt. of Agricultural Process Engineering, Vasantrao Naik Marathawada Agriculture University, Parbhani-431402, Maharashtra 